\title{
Dispositivo de seguridad para controlar mejor el tercer molar impactado durante exodoncia: Una nueva técnica
}

\author{
Security device for a better control of impacted third molars \\ during exodontia: A new technique
}

\author{
F. Hernández Altemir, S. Hernández Montero, M. Moros Peña, E. Hernández Montero
}

Resumen: El desplazamiento accidental del tercer molar impactado es una complicación que ocurre de vez en cuando durante la exodoncia. La recuperación de estos dientes accidentalmente desplazados puede ser compleja debido a la mala visibilidad y el espacio limitado. Describimos una técnica fácil basada en un sistema de anclaje para controlar mejor los terceros molares impactados durante la exodoncia.

Palabras clave: Tercer molar impactado; Sistema de anclaje; Dispositivo de seguridad; Desplazamiento durante exodoncia.

Recibido: 20-07-2004

Aceptado: 06-10-2004

\section{Introducción}

El tercer molar tiende a salir relativamente tarde y lentamente, y a menudo se presentan alteraciones asociadas con su erupción y posición, por ejemplo la pericoronitis y la impactación, en la segunda y tercera décadas de la vida. Estas alteraciones y su prevención son la justificación principal de la extracción temprana de los terceros molares. El desplazamiento accidental del tercer molar impactado, por ejemplo un fragmento de la raíz, la corona o el diente entero, es una complicación que sucede a veces durante la exodoncia. El desplazamiento del molar al seno maxilar es un problema serio, pero no

\footnotetext{
1 Jefe del Departamento de Cirugía Oral y Maxilofacial

2 Cirujano oral y maxilofacial

3 Pediatra

4 Otorrinolaringólogo

Departamento de Cirugía Oral y Maxilofacial

Hospital Universitario "Miguel de Servet", Zaragoza, España

Correspondencia:

Francisco Hernández Altemir

Calle Fray Luis Amigó nํㅛ, 0-B.

50006 Zaragoza, España

Email: drhernandezaltemir@yahoo.es
}

\begin{abstract}
Accidental displacement of impacted third molars is a complication that occasionally occurs during exodontia. The retrieval of these accidentally displaced third molars may be complex due to poor visibility and limited space. We describe an easy technique for a better control of impacted third molars during exodontia based on an anchoring system.
\end{abstract}

Key words: Impacted third molars; Anchoring system; Security device; Displacement during exodontia.

\section{Introduction}

Third molars tend to erupt relatively late and slowly, and disturbances associated with their eruption and position, for example pericoronitis and impaction, often arise in the second and third decades of life. These disturbances and their prevention are the major reasons for early removal of third molars. Accidental displacement of impacted third molars, either a root fragment, the crown or the entire tooth, is a complication that occasionally occurs during exodontia. When the molar moves to the maxillary sinus the problem is not as serious as when it gets into the pterygomandibular or infratemporal spaces. Surgeons, of course, are very much aware of this eventuality, which can cause tension and some stress during the luxation and extraction, and even more so when the surgeon is an amateur and is being helped by an experienced specialist, who probably suffers even more in his role as teacher. The surgical procedure for the retrieval of such a displaced tooth may be complex due to poor visibility and limited space. Recently a 43-year-old woman was referred urgently to our Service after a failed attempt at 
tanto como cuando se introduce en los espacios pterigomandibular o infratemporal. Los cirujanos, conscientes de esta eventualidad, sienten tensión por este motivo durante la luxación y la extracción de estos dientes, sobre todo los que están en fase de aprendizaje. El especialista experimentado puede sufre aún más que el alumno en su papel de profesor. El procedimiento quirúrgico para recuperar un molar desplazado de esta manera puede ser complejo debido a la mala visibilidad y el espacio limitado. Recientemente fue referida urgentemente una mujer de 43 años a nuestro servicio tras una tentativa fallida de exodoncia de un tercer molar superior izquierdo impactado. Su exploración radiográfica (Fig. 1) y TC (Fig. 2) demostraron desplazamiento del molar al espacio pterigomandibular.

Anestesiaron a la paciente y se inició el procedimiento quirúrgico. Para extraer el molar abordamos el espacio ampliando las incisiones de la primera tentativa exodóntica. Separamos un colgajo vestibulotuberoso que nos permitió localizar y extraer el diente sin complicaciones (Fig. 3).

Sin embargo, se han comunicado dificultades importantes en la localización del tercer molar accidentalmente desplazado a esta región. Describimos una técnica fácil para controlar mejor el tercer molar retenido en la mandíbula durante la exodoncia.

\section{Material y método}

Utilizamos un dispositivo de anclaje, desarrollado por nosotros, que se parece en algunos aspectos a dispositivos existentes que pueden también ser útiles. Sin embargo, en nuestro procedimiento el dispositivo se ancla con su hilo de seguridad a la cara vestibular y/o oclusal del molar impactado una vez que se haya expuesto quirúrgicamente. Por lo tanto, hemos hecho modificaciones instrumentales en el anclaje y en los elementos de su colocación ya que, debido a la naturaleza de la muela con su esmalte y dentina, y su posición, hace falta un instrumento especializado.

Nuestro instrumento consta de los elementos de anclaje habitualmente utilizados para fijar tendones, músculos y otros componentes en articulaciones pequeñas. En este caso se fijan al diente diana taladrando un orificio del diámetro y profundidad necesario para acomodar el dispositivo de anclaje (Fig. 4).

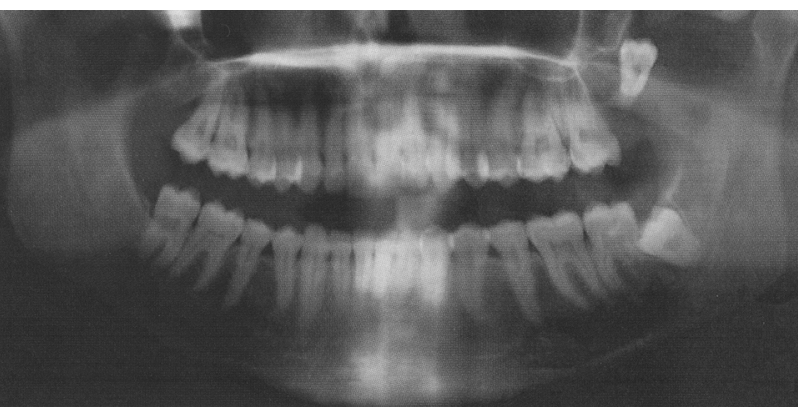

Figura 1. Diente 28 desplazado a la región pterigomandibular durante un intento de exodoncia.

Figure 1. 28 displaced to the pterygomandibular region during attempted exodontia.

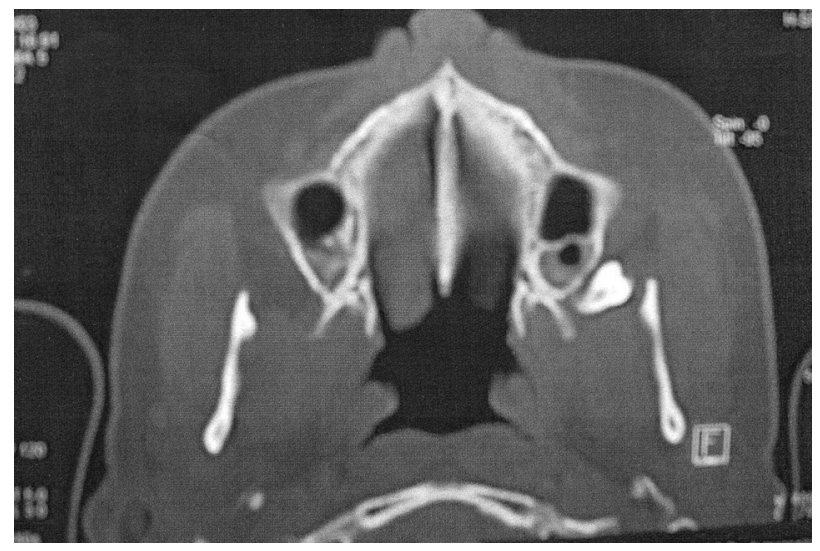

Figura 2. Sección transversa de la TC.

Figure 2. Transversal cut of CT.

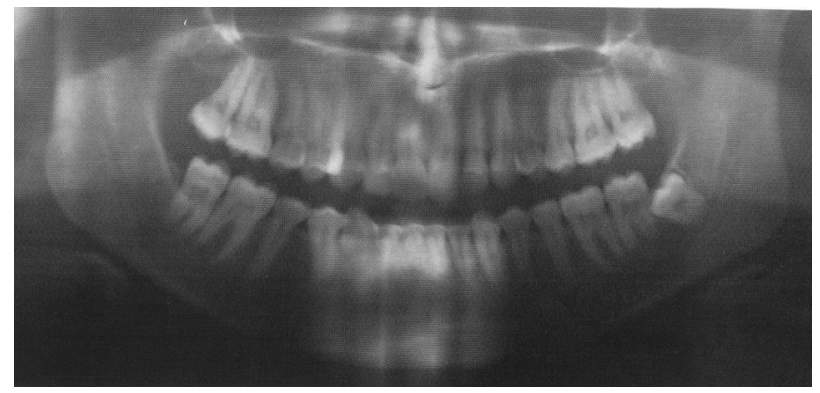

Figura 3. Comprobación postoperatoria tras extraer el diente 28. Figure 3. Post-operation check after removal of the 28. exodontia of an impacted left upper third molar. Radiographic examination (Fig. 1) and TAC (Fig. 2) showed that the molar was displaced into the pterygomandibular space.

The patient was anaesthetised and surgical procedure was initiated. To extract the molar we reached the space using and extending the incisions of the first exodontic attempt. We detached a vestibulotuberosital flap that allowed us to locate and remove the tooth with no complications (Fig. 3).

However, serious disadvantages have been reported in the location of accidentally displaced third molars to this region. We describe an easy technique for a better control of non-erupted mandibular third molars during exodontia.

\section{Material and method}

We use an anchoring device we ourselves have developed which is in some ways similar to existing devices which may also prove useful. However, given that in our procedure, the anchoring of the device with its security thread is carried out in the vestibular and/or occlusal face of the impacted molar when it has been surgically exposed, we have had to make both instrumental modifications on the anchorage itself and on the dental installation elements, that because of the nature of the molar; enamel and dentin, and its position, requires a more specialized instrument.

Our instrument consists of the anchoring devices normally used to fix tendons and muscles etc. on small joints but in this case it is fixed into the relevant tooth by drilling an orifice of exactly the right calibre and depth to fit the anchoring device (Fig. 4).

Once the vestibular/occlusal faces of the molar to be extracted have been sufficiently exposed, a drill is used to 
Las caras vestibular y oclusal del molar que se va a extraer han sido expuestas suficientemente y se ha taladrado un orificio al nivel apropiado, que depende de la posición del tercer molar retenido. Este orificio (Fig. 4A) actuará como una guía para la instalación exacta del anclaje (Fig. 4B). El anclaje está unido a un hilo quirúrgico que sirve de guía y de tracción (Fig. 4C) para localizar y extraer más fácilmente el molar si se desplaza hacia el seno o la fosa subtemporal. Esto indudablemente facilita la recuperación del molar.

\section{Discusión y conclusiones}
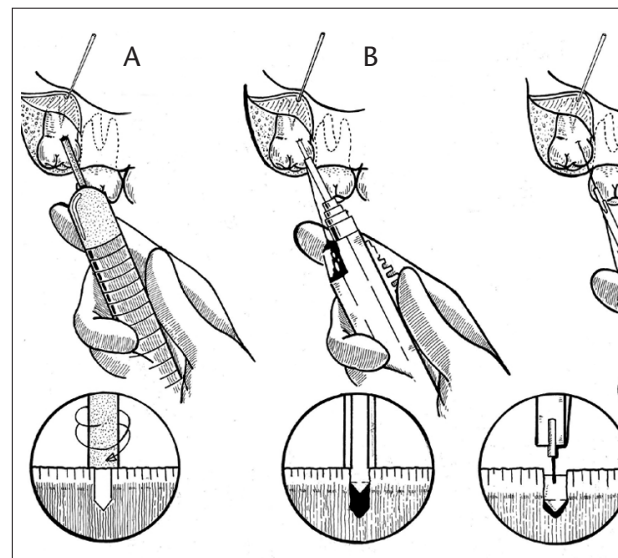

B

cado.

Figure 4. X-ray image of the molar with device inserted. make a cavity at the most appropriate level, depending on the position of the non erupted third molar, a cavity (Fig. 4A) that will act as a shroud enabling us to install our anchorage accurately (Fig. 4B). The anchorage supports a surgical thread which acts as a guide and/or a traction system (Fig. 4C) to locate and/or extract the luxated molar more easily towards the sinus or the subtemporal fossa. Thus the recovery of the molar is undoubtedly made simpler.
Es obligación nuestra proporcionar la seguridad máxima y garantías de éxito a los pacientes que se someten a procedimientos quirúrgicos. Si estas mismas medidas además alivian la tensión que siente el cirujano durante esta intervención, que se repite miles de veces al día alrededor del mundo, el uso de este dispositivo está más que justificado. Se ha comunicado repetidamente el desplazamiento de molares retenidos en la literatura, y los procedimientos quirúrgicos de su recuperación pueden llegar a ser muy complejos, especialmente si el molar se introduce en el espacio pterigomandibular o en la fosa infratemporal. En estos casos, el paciente a menudo no aprecia la complejidad de la intervención necesaria y frecuentemente tienen la misma actitud tanto los especialistas como los administradores sanitarios.

Desde que comenzamos a utilizar este procedimiento, ha disminuido el nivel de tensión entre los cirujanos que realizan la intervención. Sólo hemos tenido que hacer frente a las complicaciones descritas anteriormente una vez, en los años 70 , en un caso de tercer molar impactado que se introdujo en el seno maxilar izquierdo durante la exodoncia y precisó un procedimiento de Caldwell-Luc para su resolución. Sin embargo, este caso nos impresionó lo suficiente para motivarnos a desarrollar este dispositivo de seguridad que tiene ventajas obvias, aunque también alarga el tiempo de la intervención, implica el uso de instrumentos adicionales y aumenta el costo.

\section{Bibliografía}

1. Sisk AL, Hammer WB, Shelton WD, Joy ED. Complications following removal of impacted third molars: the role of the experience of the surgeon. J Oral MaxiIlofac Surg 1986;44:855-9.

2. Chiapasco M, De Cicco L, Marrone G. Side effects and complications associated with third molar surgery. Oral Surg Oral Med Oral Pathol 1993;76:412-20.

3. De Boer MP], Raghoebar GM, Stegenga B, Schoen PJ, Boering G. Complications after mandibular third molar extraction. Quintessence Int 1995;26:779-84.

4. Yeh C. A simple retrieval technique for accidentally displaced mandibular third molars. J Oral Maxillofac Surg 2002;60:836-7.

5. Orr II DL. A technique for recovery of a third molar from the infratemporal fossa: Case report. J Oral Maxillofac Surg 1999;57:1459-61.

\section{Discussion and conclusions}

Providing maximum safety and guarantee of success to the patient in any surgical procedure is, of course, an obligation. If, at the same time the surgeon benefits with a reduction in stress during this operation, which is, repeated thousands of times every day around the world, then the use of this device is more than justified. Moreover, the displacement of non erupted molars is repeatedly referred to in the literature, and surgical procedures for their retrieval may be very complex, especially if the molar gets into the pterygomandibular space or the infratemporal fossa when the complexity of the surgery required is often underestimated by the patient and not infrequently by specialists and Health Managers too.

Since we began to use this procedure, stress levels during surgery have been reduced. We have only encountered the complications mentioned above once, in the 1970s, when there was a case of an impacted third molar that moved to the left maxilla sinus during exodontia and required a Caldwell-Luc procedure to be carried out. However, this case made an impression on us and lead us to develop this safety device which, in spite of its obvious advantages, also prolongs surgery time, implies additional use of instruments and consequently greater expense. 